\title{
Epithelioid Hemangioendothelioma
}

National Cancer Institute

\section{Source}

National Cancer Institute. Epithelioid Hemangioendothelioma. NCI Thesaurus. Code C3800

A low-grade malignant blood vessel neoplasm. It is characterized by the presence of epithelioid endothelial cells. The neoplastic cells are arranged in cords and nests, which are embedded in a myxoid to hyalinized stroma. 